\title{
PENGEMBANGAN SOFTWARE ANTI CHEMMISCO DENGAN STRATEGI CONCEPTUAL CHANGE TEXT PADA MATERI LAJU REAKSI
}

\section{THE DEVELOPMENT SOFTWARE ANTI CHEMMISCO WITH CONCEPTUAL CHANGE TEXT STRATEGIES IN REACTION RATE MATERIAL}

\author{
Nabila Yuniar Mandasari dan *Sukarmin \\ Jurusan Kimia FMIPA Universitas Negeri Surabaya
}

Email: sukarmin@unesa.ac.id

\begin{abstract}
Abstrak
Penelitian pengembangan ini memiliki tujuan untuk mengembangkan software anti chemmisco sebagai media pendeteksi dan pereduksi miskonsepsi peserta didik dengan strategi conceptual change text pada materi laju reaksi. Pengembangan software ini ditinjau berdasarkan kelayakan software dari tiga kriteria. Kelayakan software yang dikembangkan ditinjau dari validitas, kepraktisan dan keefektifan. Metode yang digunakan dalam pengembangan software ini yaitu metode Research and Development (R\&D). Uji coba terbatas dilakukan dengan subyek 15 peserta didik di SMA Negeri 1 Krembung Sidoarjo. Hasil dari penelitian yang diperoleh menunjukkan bahwa software dikatakan layak digunakan sebagai media pendeteksi dan pereduksi miskonsepsi peserta didik dalam materi laju reaksi. Hal ini dibuktikan dengan hasil dari validasi isi yang mendapatkan persentase rata-rata sebesar 94,65\% dan validasi konstruk memperoleh 91,99\% dimana termasuk kategori sangat valid. Kepraktisan dari hasil angket respon peserta didik termasuk kategori sangat praktis dengan persentase rata-rata sebesar $96 \%$ dan aktivitas peserta didik sebesar $100 \%$ dengan kriteria sangat praktis. Keefektifan ditinjau dari hasil pergeseran atau perubahan konsepsi peserta didik dari miskonsepsi menjadi paham konsep termasuk kategori sangat efektif dengan persentase rata-rata sebesar $91,64 \%$.
\end{abstract}

Kata kunci: Software Anti Chemmisco, Conceptual change text, Laju Reaksi.

\begin{abstract}
This research development has the aim to develop an anti chemmisco software as a medium for detecting and reducing misunderstandings students with conceptual text change strategies in reaction rate material. Software development is reviewed based on the proprietary software of the three criteria.. The method used in this software development is a method of research and development $R \& D)$. Limited trials were conducted with the subject of 15 students in Senior High School 1 Krembung Sidoarjo. The results obtained indicate that the software is said to be suitable for use as a medium for detecting and reducing student's misconceptions in the material reaction rate. This is evidenced by the results of validation of content to get the average percentage of $94.65 \%$ and $91.99 \%$ construct validation categorized obtain very valid. Practicality results of the student questionnaire responses included very practical category with an average percentage of $96 \%$ and student activity $100 \%$ with very practical criteria.. The effectiveness in terms of outcomes of major shifts in student's conceptions of misunderstanding understand the concept, including the category of very effective with an average percentage of $91.64 \%$.
\end{abstract}

Keywords: Anti Chemmisco Software, Conceptual change text, Reaction Rate.

\section{PENDAHULUAN}

Salah satu dalam ilmu sains yang sangat berkaitan dengan konsep abstrak dan struktur materi yang kompleks yaitu ilmu kimia [1]. Ilmu kimia merupakan bagian dari ilmu yang berisi fakta, konsep, hukum, teori yang diperoleh melalui proses dan analisis ilmiah yang berkaitan dengan sifat, struktur, reaksi, perubahan energi dan materi. Kajian utama dalam kimia adalah konsep [2].
Konsep merupakan kumpulan stimulus yang memiliki atribut sama sehingga seseorang mampu membedakan atribut konsep antara konsep satu dengan lainnya [3]. Berdasarkan definisi konsep yang dikaitkan dengan kondisi pengetahuan peserta didik saat ini, kemungkinan terjadi miskonsepsi pada peserta didik disebabkan adanya kesulitan peserta didik dalam mempelajari konsep kimia [4].

Miskonsepsi merupakan kesalahan konsep yang disebabkan karena pada saat pembelajaran 
berlangsung terjadi ketidaksesuaian dengan konsep ilmiahnya [3]. Peserta didik yang mengalami miskonsepsi harus segera dideteksi dan direduksi sehingga miskonsepsi dalam salah satu konsep tidak berdampak pada pemahaman konsep selanjutnya [5].

Tes diagnostik adalah salah satu cara untuk mendeteksi peserta didik yang mengalami miskonsepsi. Metode tes diagnostik yang digunakan dalam penelitian ini adalah tes diagnostik empat tingkat (four tier diagnostic test) [6]. Tes diagnostik empat tingat terdiri dari soal pilihan ganda dengan satu kunci jawaban dan empat pengecoh, tingkat keyakinan jawaban peseta didik dalam memilih jawaban, alasan peserta didik menjawab pertanyaan yang berupa alasan tertutup dan tingkat keyakinan peserta didik dalam memberi alasan [6]

Salah satu konsep yang sering terjadi miskonsepsi dalam materi kimia adalah laju reaksi. Untuk menentukan konsep yang paling banyak terjadi miskonsepsi pada peserta didik, peneliti melakukan studi lapangan berupa pra-penelitian di tiga sekolah yang berbeda. Berdasarkan hasil prapenelitian menunjukkan bahwa di SMAN 1 Porong persentase miskonsepsi peserta didik pada materi laju reaksi sebesar $72,13 \%, 50,25 \%$ di SMAN 3 Pamekasan dan 71,58\% di SMAN 1 Krembung. Hasil pra-penelitian tersebut menunjukkan bahwa masih banyak peserta didik yang mengalami miskonsepsi pada konsep laju reaksi.

Miskonsepsi yang terdiagnosa pada peserta didik tidak dapat dibiarkan sehingga diperlukan upaya dalam mereduksi miskonsepsi. Terdapat beberapa metode untuk mereduksi miskonsepsi yang terjadi yaitu dengan menerapkan model pembelajaran yang dibantu dengan kerja kelompok, diskusi, komputer, pengunaan conceptual change dan demonstrasi [7].

Pada strategi pembelajaran conceptual change text perubahan konsepsi peserta didik yang mendasarkan diri pada pemahaman konstruktivisme berbasis keterampilan berpikir [8]. Strategi conceptual change text memiliki 4 fase yaitu menunjukkan konsepsi peserta didik, menciptakan konflik konseptual, proses equilibrasi, dan rekonstruksi konsep [9].

Terkait penggunaan strategi dan metode yang tepat, penggunaan media pembelajaran memiliki peran yang sangat penting pula. Software yang dikembangkan digunakan untuk mendeteksi miskonsepsi peserta didik dan meremidiasi miskonsespsi [10].

Berdasarkan hasil penelitian sebelumnya terkait uji coba pengembangan software pendeteksi dan pereduksi miskonsepsi berbasis conceptual change text mampu mendeteksi miskonsepsi kimia [11]. Hal ini dibuktikan dengan hasil pergeseran konsepsi peserta didik yaitu perubahan konsepsi peserta didik dari 10 soal pada tes pertama dan berkurang menjadi 3 butir soal pada tes kedua [12].

Seperangkat tes diagnostik empat tingkat dan conceptual change text disajikan dengan media yang menampilkan informasi dalam bentuk visual dan verbal yang dikemas menjadi sebuah software [13]. Software yang disajikan berupa multimedia interaktif yang cocok digunakan untuk menyampaikan konsep kimia terkait tiga level representasi kimia. Selain itu, software ini juga digunakan untuk mendeteksi dan mereduksi miskonsepsi pada materi kimia secara cepat, efektif dan efisien [14]. Tujuan dilakukan penelitian ini adalah untuk mengetahui kelayakan software pada materi laju reaksi yang dikembangkan berdasarkan kevalidan, kepraktisan dan keefektifan.

\section{METODE}

Penelitian ini menggunakan metode pengembangan research and development $(\mathrm{R} \& \mathrm{D})$ yang mengacu pada model pengembangan Sugiyono. Metode ini memiliki 10 langkah namun software yang dikembangkan hanya sampai tahap uji coba produk. Alur penelitian R\&D disajikan oleh Gambar 1.

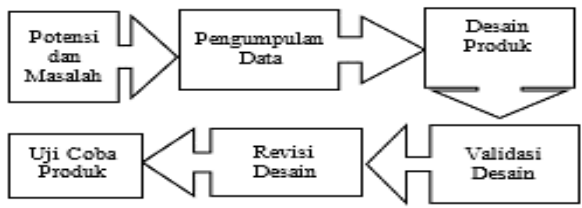

Gambar 1. Alur Penelitian R\&D [15]

Langkah-langkah dalam penelitian yaitu: (1) Potensi dan masalah, (2) Pengumpulan data, (3) Desain produk, (4) Validasi desain, (5) Revisi Desain dan (6) Uji coba produk. Uji coba software terhadap 15 peserta didik SMAN 1 Krembung kelas XI IPA 5 yang telah mendapatkan materi laju reaksi dan yang memiliki kriteria miskonsepsi tertinggi.

Kelayakan software anti chemmisco ditinjau dari 3 kriteria yaitu kevalidan, kepraktisan dan keefektifan. kevalidan software ditinjau 
berdasarkan penilaian hasil validasi isi dan konstruk. Penilaian dalam kevalidan software dilakukan oleh tiga validator yang ahli dibidangnya. Validitas dinilai menggunakan skala likert dengan skor 1-5 [16]. Software dinyatakan valid apabila persentasenya $\geq 61 \%$. Persentase hasil validasi isi dan konstruk ditentukan berdasarkan rumus:

$$
\mathrm{P}(\%)=\frac{\text { skor yang didapat }}{\text { skor maksimal }} \times 100 \%
$$

Kepraktisan ditinjau dari hasil yang diperoleh dari respon peserta didik yang didukung dengan hasil observasi peserta didik. Hasil respon dan juga observasi peserta didik dinilai menggunakan skala Guttman [16]. Software dinyatakan praktis apabila persentasenya $\geq 61 \%$. Persentase hasil respon dan observasi peserta didik ditentukan berdasarkan rumus:

$$
\mathrm{P}(\%)=\frac{\text { skor responden yang memilih }}{\text { skor kriteria }} \times 100 \%
$$

Keefektifan diperoleh berdasarkan hasil pergeseran konsepsi peserta didik dari miskonsepsi menjadi tahu konsep berdasarkan hasil pretest dan postest. Software dinyatakan efektif apabila persentasenya $\geq 61 \%$. Persentase hasil konsepsi peserta didik ditentukan berdasarkan rumus:

$$
P(\%)=\frac{2 M-P K}{\sum M \text { awal }} x 100 \%
$$

Dimana:

$\boldsymbol{\Sigma}$ M-PK = jumlah pergeseran konsep dari miskonsepsi ke tahu konsep

$\boldsymbol{\Sigma}$ Mawal $=$ jumlah miskonsepsi awal sebelum bergeser

\section{HASIL DAN PEMBAHASAN}

Software yang dikembangkan berisi pendeteksi miskonsepsi berupa soal dengan metode four tier diagnostic test dan pereduksi miskonsepsi berdasarkan strategi conceptual change text. Pengembangan software diuji kelayakannya yang ditinjau berdasarkan kevalidan, kepraktisan dan keefektifan. Adapun hasil penelitian terkait pengembangan software diuraikan sebagai berikut:

\section{a. Potensi dan Masalah}

Hasil studi lapangan menunjukkan bahwa saat ini sekolah seperti SMA Negeri 1 Krembung Sidoarjo dilengkap fasilitas laboratorium komputer dan WiFi. Selain hal tersebut, berasarkan hasil studi lapangan di SMAN 1 Krembung menunjukkan masih ada masalah dalam pembelajaran yaitu masih ada $72 \%$ peserta didik yang mengalami miskonsepsi.

Melihat potensi dan masalah tersebut maka pengembangan software pendeteksi dan pereduksi miskonsepsi sangat diperlukan dalam pembelajaran. Software yang digunakan sebagai pendeteksi dan pereduksi miskonspsi pada materi laju reaksi disajikan dalam bentuk media interaktif. Software dapat dijalankan melalui komputer, laptop atau android yang telah terinstal flash player.

\section{b. Pengumpulan Data}

Berdasarkan studi literatur diperoleh data bahwa terjadi miskonsepsi di SMAN 2 Malang pada sub bahasan persamaan laju reaksi sebanyak $75,5 \%$, orde reaksi sebanyak $55,1 \%$, faktor-faktor yang memperngaruhi laju reaksi $41,2 \%$ dan teori tumbukan sebanyak 40,8\% [17]. Dari data tersebut diperlukan penelitian lebih lanjut untuk mengatasi miskonsepsi pada laju reaksi.

Penelitian awal di tiga sekolah, antara lain SMA Negeri 1 Porong, SMA Negeri 1 Krembung dan SMA Negeri 3 Pamekasan. Peneliti memberikan soal kepada peserta didik kelas XII tentang beberapa konsep pada materi laju reaksi. Diperoleh hasil peserta didik yang mengalami miskonsepsi pada konsep definisi laju reaksi sebesar 75\%, 60\% pada faktor luas permukaan, $57 \%$ pada faktor suhu dan $66 \%$ pada faktor katalis.

Dari data-data diatas diketahui bahwa miskonsepsi dalam materi laju reaksi benar-benar ada sehingga peneliti membuat rancangan produk yang digunakan untuk mengatasi permasalahan ini.

\section{c. Desain Produk}

Berdasarkan potensi dan masalah melalui studi literatur serta hasil pra-penelitian sebelumnya, peneliti mengembangakan software yang digunakan untuk mendeteksi dan mereduksi miskonsepsi pada materi laju reaksi. Software yang dikembangkan berisi pendeteksi miskonsepsi berupa soal dengan metode four tier diagnostic test dan pereduksi miskonsepsi berdasarkan strategi conceptual change text. Software ini dibuat dengan bahasa pemrograman Hyper Text Prepocessor (PHP) didukung dengan beberapa aplikasi seperti Adobe Flash CS6, Adobe Photoshop CS3 dan VSDC Free Video Editor. Software yang dikembangkan diberi nama software anti chemmisco. Adapun hasil desain produk software sebagai berikut: 
1. Halaman Login

Pada bagian halaman awal login terdapat kolom username dan password yang harus diisi. Setelah masuk halaman login akan terdapat pilihan menu, diantaranya: peserta didik, soal, hasil ujian, master data, petunjuk, dan logout. Tampilan halaman login peserta didik dapat dilihat pada gambar 1 .

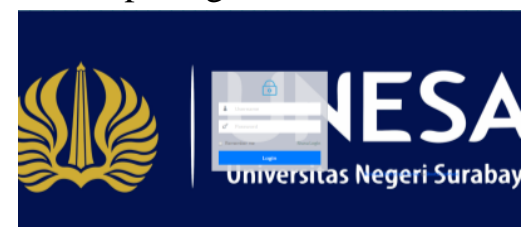

Gambar 1. Halaman Login Peserta Didik

2. Halaman Menu Utama

Setelah login, muncul tampilan menu utama yang berisi nama peserta didik, NIS, kode paket, pilihan konsep yang akan dikerjakan, menu petunjuk dan logout. Sebelum mengerjakan, peserta didik membaca petunjuk yang telah ditampilkan pada menu utama. Tampilan halaman menu utama dapat dilihat pada gambar 2.

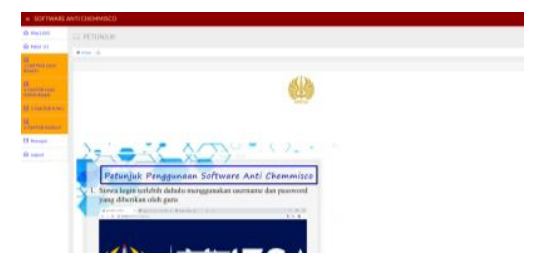

Gambar 2. Tampilan Menu Utama

3. Halaman Petunjuk

Pada halaman petunjuk berisi petunjuk cara penggunaan software untuk peserta didik. Halaman petunjuk dibuat dengan menggunakan aplikasi adobe flash CS6. Tampilan halaman petunjuk dapat dilihat pada gambar 3 .

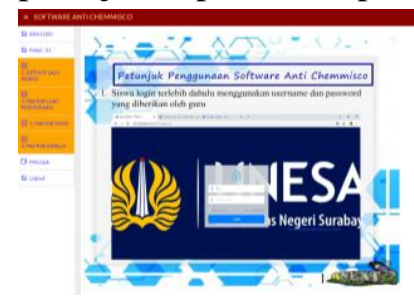

Gambar 3. Tampilan Halaman Petunjuk

\section{Soal Pretest}

Setelah peserta didik membaca petunjuk penggunaan software, peserta didik memilih konsep yang akan dikerjakan secara berurutan. Peserta ddik akan diberikan beberapa soal pretest dengan instrumen model four-tier test. Apabila peserta didik terdeteksi miskonsepsi atau tidak tahu konsep, peserta didik diberi peringatan dan diarahkan ke tombol HELP/MATERI untuk memperbaiki konsep yang dimiliki. Tampilan menu soal pretest dapat dilihat pada gambar 4 .

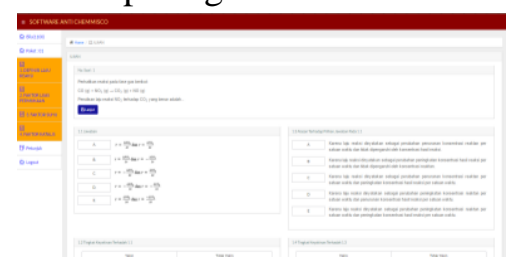

Gambar 4. Tampilan Menu Soal Pretest

\section{Menu Conceptual change text}

Halaman pereduksi miskonseps peserta didik diajikan dengan strategi conceptual change text yang terdiri dari empat tahap yaitu: (1) menunjukkan konsepsi peserta didik yang termuat dalam CCT 1 pada software, (2) menciptakan konflik kognitif yang termuat dalam CCT 2 pada software, (3) proses equilibrasi yang termuat dalam CCT 3 pada software dan (4) rekonstruksi konsep konsep yang termuat dalam CCT 4 pada software [9]. Tampilan conceptual change text dapat dilihat pada gambar 5 .

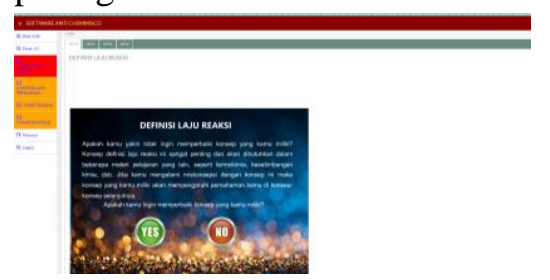

Gambar 5. Tampilan Conceptual Change Text

\section{d. Validasi Desain}

Hasil dari validasi yang dinilai oleh orang yang ahli di bidangnya terhadap software anti chemmisco yang dikembangkan. Software anti chemmisco dinyatakan valid apabila persentase hasilnya $\geq 61 \%$. Validasi software ini diperoleh berdasarkan validasi isi dan validasi konstruk. Adapun rincian hasil validasi isi disajikan pada Tabel 1.

Tabel 1. Hasil Validasi Isi Software

\begin{tabular}{lcc}
\hline \multicolumn{1}{c}{$\begin{array}{c}\text { Aspek yang } \\
\text { Dinilai }\end{array}$} & $\begin{array}{c}\text { Persentase } \\
(\%)\end{array}$ & Kriteria \\
\hline $\begin{array}{l}\text { Kebenaran materi } \\
\text { dalam software }\end{array}$ & 93,33 & $\begin{array}{c}\text { Sangat } \\
\text { valid }\end{array}$ \\
$\begin{array}{l}\text { Kesesuaian soal } \\
\text { dalam software }\end{array}$ & 93,33 & $\begin{array}{c}\text { Sangat } \\
\text { valid }\end{array}$ \\
$\begin{array}{l}\text { Penggunaan } \\
\text { bahasa dalam } \\
\text { software }\end{array}$ & 95,55 & $\begin{array}{c}\text { Sangat } \\
\text { valid }\end{array}$ \\
\hline
\end{tabular}


Berdasarkan pada Tabel 1 terdapat tiga kriteria penilaian. Kriteria pertama yaitu kebenaran materi dalam software mendapat persentase sebesar 93,33\%. Hal itu menunjukkan bahwa konsep yang disajikan dalam software telah benar, menggunakan simbol, angka dan rumus yang tepat sehingga tidak berpotensi menimbulkan miskonsepsi. Kesesuaian antara materi dengan media pembelajaran berdampak pada hasil belajar peserta didik [18].

Kriteria kedua yaitu kesesuaian soal dalam software sebesar 93,33\%. Hal tersebut berarti butirbutir soal yang disajikan dalam software merupakan butir soal yang dapat mewakili konsep materi laju reaksi, butir soal yang disajikan dalam software dapat digunakan untuk mendeteksi konsepsi peserta didik, serta sesuai dengan KD yang diatur oleh kemendikbud kurikulum 2013 revisi [18].

Kriteria penggunaan bahasa dalam software sebesar 95,55\%. Hal tersebut berarti software telah menggunakan bahasa yang baik, benar dan tidak menimbulkan penafsiran ganda. Aspek bahasa dipertimbangkan karena salah satu hal yang menyebabkan miskonsepsi adalah peserta didik sulit memahami bahasa selama pembelajaran [19]. Secara keseluruhan validitas isi mendapat rata rata persentase sebesar 94,07\% dan termasuk kategori sangat valid.

Adapun hasil dari penilaian validasi konstruk ditunjukkan pada Tabel 2.

Tabel 2. Hasil Validasi Konstruk

\begin{tabular}{lcc}
\hline Aspek yang Diamati & $\begin{array}{c}\text { Persentase } \\
(\%)\end{array}$ & Kriteria \\
\hline Tampilan software & 91,67 & $\begin{array}{c}\text { Sangat } \\
\text { valid }\end{array}$ \\
Penggunaan software & 91,11 & $\begin{array}{c}\text { Sangat } \\
\text { valid }\end{array}$ \\
$\begin{array}{l}\text { Kepraktisan software } \\
\text { dalam mereduksi } \\
\text { miskonsepsi }\end{array}$ & 93,33 & $\begin{array}{c}\text { Sangat } \\
\text { valid }\end{array}$ \\
\hline
\end{tabular}

Berdasarkan Tabel 2 diketahui hasil persentase validasi konstruk. Pada validasi konstruk terdapat 3 kriteria penilaian. Kriteria pertama yaitu keserasian tampilan software mendapat persentase sebesar $91,67 \%$ dan termasuk kategori sangat valid. Hal ini menunjukkan bahwa background serta warna yang dipilih pada desain software secara umum, jenis huruf dan warna yang dipilih telah serasi [18].
Kriteria kedua yaitu penggunaan software mendapat persentase rata-rata sebesar $91,11 \%$. Hal ini berarti bahwa software mudah untuk digunakan setelah membaca petunjuk yang ada, hasil pekerjaan peserta didik yang direkam oleh software dapat dibaca dan dipahami dengan mudah serta sesuai dengan realita jawaban peserta didik. Kemudahan akses menjadi pertimbangan dalam pengembangan media pembelajaran [19]. Kemudahan akses juga memudahkan guru dalam memperoleh informasi hasil belajar peserta didik [20].

Kriteria ketiga yaitu kepraktisan software dalam mereduksi miskonsepsi memperoleh persentase sebesar 93,33\% dan termasuk kategori sangat praktis. Hal tersebut menunjukkan bahwa dalam software telah ada komponen untuk mendeteksi dan mereduksi miskonsepsi. Pada tahap pretest, terdapat soal menggunakan instrumen fourtier test. Instrumen tersebut dipilih karena instrumen terbaru yang menyempurnakan kekurangan metode three-tier test serta membutuhkan waktu yang lebih singkat daripada metode konvensional [21].

\section{e. Revisi Desain}

Peneliti memperbaiki desain software berdasarkan saran yang diberikan oleh validator. Peneliti memperoleh revisi desain dan revisi instrumen penelitian. Hasil revisi software sebagai berikut:

1. Mengubah posisi tombol lanjut pada software dari bawah soal tier keempat menjadi diatas soal tier pertama. Tata letak (layout) diperlukan untuk mempermudah akses dan kenyamanan peserta didik dalam membaca [22].

2. Memperbesar ukuran teks yang terdapat pada software. Besar-kecilnya elemen visual terutama ukuran teks perlu diperhitungkan secara tepat sehingga software memiliki nilai kemudahan baca yang tinggi [23].

3. Mengubah halaman awal (menu utama) software yang langsung ke soal pada konsep pertama menjadi halaman petunjuk penggunaan software. Menu utama atau disebut navigasi utama pada software harus terlihat lebih menarik dan berisi informasi penggunaan software [22].

4. Mengubah simbol rumus hukum laju reaksi dengan simbol yang benar. Penggunaan simbol rumus harus tepat agar menciptakan pembelajaran yang bermakna [24]. 


\section{f. Uji Coba Produk}

Uji coba software dilakukan kepada 15 peserta didik kelas XI IPA 5 SMAN 1 Krembung. Uji coba software bertujuan untuk mengetahui kepraktisan dan keefektifan software. Kepraktisan software ditinjau dari hasil angket respon peserta didik sebagai pengguna software. Rincian-rincian hasil penilaian respon peserta didik ditampilkan pada Tabel 3.

Tabel 3. Hasil Respon Peserta Didik

\begin{tabular}{|c|c|c|c|}
\hline No. & $\begin{array}{l}\text { Aspek yang } \\
\text { Diamati }\end{array}$ & $\begin{array}{c}\text { Persentase } \\
(\%)\end{array}$ & Kriteria \\
\hline 1. & $\begin{array}{l}\text { Software mampu } \\
\text { meningkatkan rasa } \\
\text { ingin tahu peserta } \\
\text { didik }\end{array}$ & 100 & $\begin{array}{l}\text { Sangat } \\
\text { praktis }\end{array}$ \\
\hline 2. & $\begin{array}{l}\text { Kejelasan bahasa } \\
\text { dalam software }\end{array}$ & 100 & $\begin{array}{l}\text { Sangat } \\
\text { praktis }\end{array}$ \\
\hline 3. & $\begin{array}{lr}\text { Software mampu } \\
\text { mempermudah } \\
\text { peserta didik dalam } \\
\text { memahami } \\
\text { yang } & \text { disusun } \\
\text { melalui } & \text { strategi } \\
\text { conceptual } & \text { change } \\
\text { text } & \end{array}$ & 100 & $\begin{array}{l}\text { Sangat } \\
\text { praktis }\end{array}$ \\
\hline 4. & $\begin{array}{l}\text { Tingkat motivasi } \\
\text { belajar peserta didik } \\
\text { dengan } \\
\text { menggunakan } \\
\text { software }\end{array}$ & 90 & $\begin{array}{l}\text { Sangat } \\
\text { praktis }\end{array}$ \\
\hline & Rata-rata & $96 \%$ & $\begin{array}{l}\text { Sangat } \\
\text { praktis }\end{array}$ \\
\hline
\end{tabular}

Berdasarkan data yang ditunjukkan Tabel 3 , angket yang berisi respon peserta didik ini terdiri dari empat kriteria penilaian. Kriteria penilaian pertama yaitu software mampu meningkatkan rasa ingin tahu peserta didik diperoleh persentase sebesar $100 \%$ dan termasuk kategori sangat praktis. Hal tersebut menunjukkan bahwa sebagai pengguna, peserta didik merasa materi yang disajikan jelas dan peserta didik mendapat kepuasan telah menggunakan software ini. Penilaian peserta didik mendukung nilai validasi konsep yang disajikan dalam software dan telah memenuhi aspek kesesuaian materi [18].

Kriteria penilaian kedua yaitu kejelasan bahasa dalam software mendapat persentase sebesar $100 \%$ yang termasuk kategori sangat praktis. Hal ini menunjukkan bahwa bahasa yang digunakan dalam software mudah dimengerti dan jelas.

Kriteria penilaian ketiga yaitu software mampu mempermudah peserta didik dalam memahami materi yang disusun melalui strategi conceptual change text dan diperoleh persentase sebesar $100 \%$ yang termasuk dalam kategori sangat praktis. Hal tersebut membuktikan bahwa software yang digunakan mampu mempermudah peserta didik baik dalam penggunaan maupun memahami materi yang terdapat pada software. Hal ini merupakan salah satu syarat intruksional media edukatif [20].

Kriteria penilaian keempat yaitu tingkat motivasi belajar peserta didik dengan menggunakan software mendapat persentase sebesar $90 \%$ dan termasuk dalam kategori sangat praktis. Salah satu dasar pertimbangan dalam pengembangan dan pemilihan media pembelajaran yaitu motivasi [25].

Selain itu, kepraktisan software anti chemmisco diperoleh berdasarkan penilaian hasil observasi aktivitas peserta didik didukung dengan data hasil respon peserta didik. Adapun rincianrincian data hasil dari observasi aktivitas peserta didik ditunjukkan pada Tabel 4.

Tabel 4. Hasil Observasi Aktivitas Peserta Didik

\begin{tabular}{|c|c|c|c|}
\hline No. & $\begin{array}{c}\text { Aspek yang } \\
\text { Diamati }\end{array}$ & $\begin{array}{c}\text { Persentase } \\
(\%)\end{array}$ & Kriteria \\
\hline 1. & $\begin{array}{l}\text { Peserta didik dapat } \\
\text { login software } \\
\text { dengan baik (tidak } \\
\text { mengajukan } \\
\text { pertanyaan) }\end{array}$ & 100 & $\begin{array}{l}\text { Sangat } \\
\text { Praktis }\end{array}$ \\
\hline 2. & $\begin{array}{l}\text { Peserta didik } \\
\text { membaca petunjuk } \\
\text { penggunaan } \\
\text { software } \\
\text { chemmisco anti }\end{array}$ & 100 & $\begin{array}{l}\text { Sangat } \\
\text { Praktis }\end{array}$ \\
\hline 3. & $\begin{array}{lr}\text { Peserta } & \text { didik } \\
\text { mengerjakan } & \text { tiga } \\
\text { soal pretest } & \text { secara } \\
\text { mandiri } & \end{array}$ & 100 & $\begin{array}{l}\text { Sangat } \\
\text { Praktis }\end{array}$ \\
\hline 4. & $\begin{array}{l}\text { Peserta didik yang } \\
\text { terdeteksi } \\
\text { miskonsepsi/ tidak } \\
\text { tahu konsep } \\
\text { membaca } \\
\text { conceptual change } \\
\text { text tahap 1 }\end{array}$ & 100 & $\begin{array}{l}\text { Sangat } \\
\text { Praktis }\end{array}$ \\
\hline 5. & $\begin{array}{l}\text { Peserta didik yang } \\
\text { terdeteksi } \\
\text { miskonsepsi/ tidak }\end{array}$ & 100 & $\begin{array}{l}\text { Sangat } \\
\text { Praktis }\end{array}$ \\
\hline
\end{tabular}




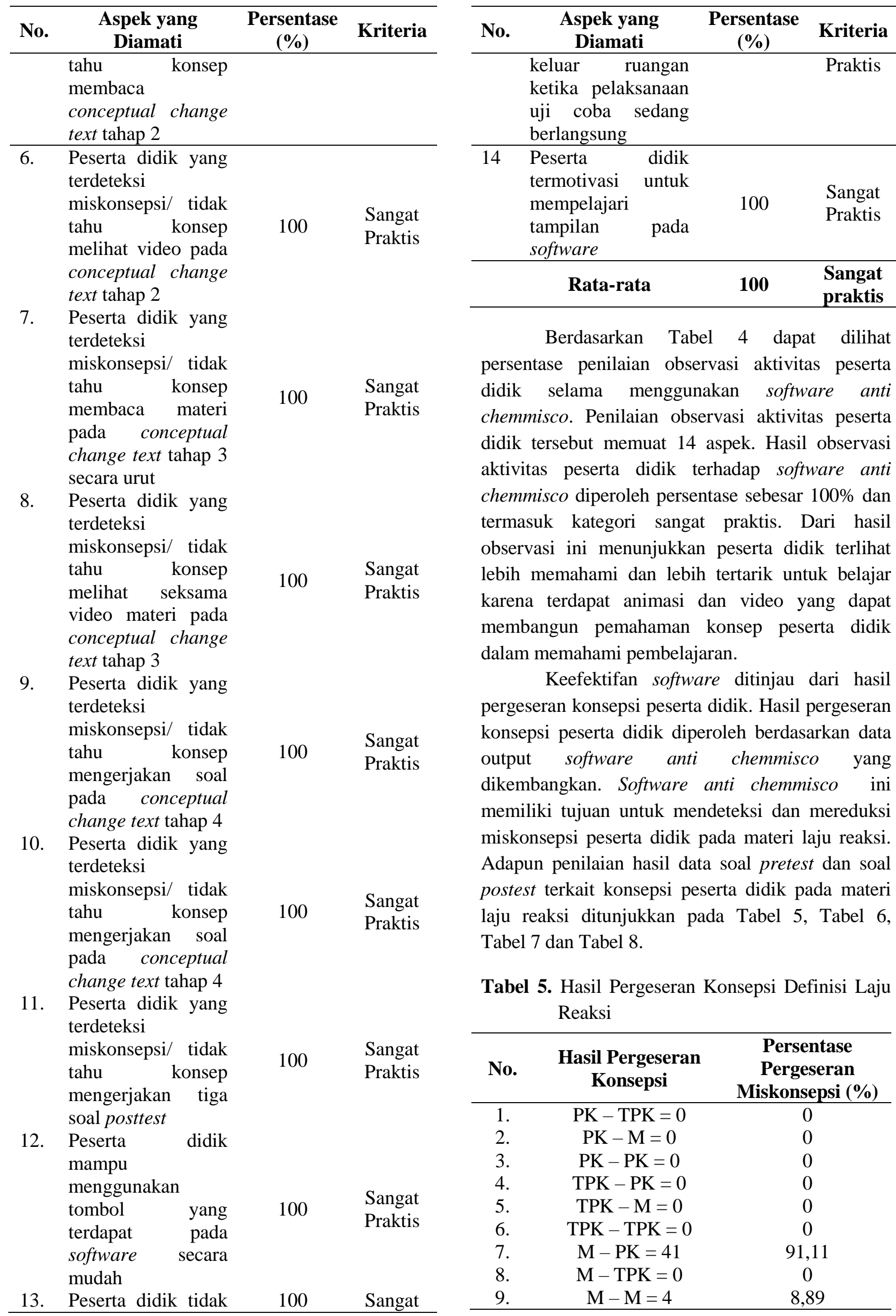


Keterangan:

PK = Paham Konsep

TPK $=$ Tidak Paham Konsep

$\mathrm{PK}=$ Paham Konsep

$\mathrm{M}=$ Miskonsepsi

Berdasarkan Tabel 5 didapatkan hasil penilaian pergeseran konsepsi peserta didik terhadap konsep definisi laju reaksi diperoleh persentase rata-rata pergeseran miskonsepsi menjadi tahu konsep sebesar 91,11\%. Pada konsep definisi laju reaksi terdapat 41 peserta didik yang terdiagnosa mengalami pergeseran konsep dan 4 peserta didik yang tidak mengalami perubahan konsep atau tetap mengalami miskonsepsi. Hal ini disebabkan karena peserta didik mengalami kesulitan atau kurang mampu memahami dan menangkap konsep yang benar terutama pada konsep abstrak [26]. Hal tersebut sesuai dengan teori perkembangan kognitif dari Piaget mengenai tahap operasioanl formal. Ketika peserta didik tidak mampu melewati tahap operasional formal (berpikir abstrak), maka peserta didik akan kesulitan menerima dan memahami materi serta tetap mengalami miskonsepsi [13].

Tabel 6. Hasil Pergeseran Konsepsi Faktor Luas Permukaan Terhadap laju Reaksi

\begin{tabular}{ccc}
\hline No. & $\begin{array}{c}\text { Hasil Pergeseran } \\
\text { Konsepsi }\end{array}$ & $\begin{array}{c}\text { Persentase } \\
\text { Pergeseran } \\
\text { Miskonsepsi (\%) }\end{array}$ \\
\hline 1. & PK - TPK $=0$ & 0 \\
2. & $\mathrm{PK}-\mathrm{M}=0$ & 0 \\
3. & $\mathrm{PK}-\mathrm{PK}=0$ & 0 \\
4. & $\mathrm{TPK}-\mathrm{PK}=0$ & 0 \\
5. & $\mathrm{TPK}-\mathrm{M}=0$ & 0 \\
6. & $\mathrm{TPK}-\mathrm{TPK}=0$ & 0 \\
7. & $\mathrm{M}-\mathrm{PK}=39$ & 86,67 \\
8. & $\mathrm{M}-\mathrm{TPK}=0$ & 0 \\
9. & $\mathrm{M}-\mathrm{M}=6$ & 13,33 \\
\hline
\end{tabular}

Berdasarkan data yang terdapat pada Tabel 6 didapatkan persentase hasil dari pergeseran konsepsi peserta didik pada konsep faktor luas permukaan terhadap laju reaksi sebesar $86,67 \%$. Pada konsep faktor luas permukaan terhadap laju reaksi terdapat 39 peserta didik yang terdiagnosa mengalami pergeseran konsep dan 6 peserta didik yang tidak mengalami perubahan konsep atau tetap mengalami miskonsepsi. Hal ini disebabkan karena ketidakmampuan siswa melewati tahap operasional formal (berpikir abstrak) pada teori perkembangan kognitif dari Piaget [13].

Tabel 7. Hasil Pergeseran Konsepsi Faktor Suhu Terhadap Laju Reaksi

\begin{tabular}{ccc}
\hline No. & $\begin{array}{c}\text { Hasil Pergeseran } \\
\text { Konsepsi }\end{array}$ & $\begin{array}{c}\text { Persentase } \\
\text { Pergeseran } \\
\text { Miskonsepsi (\%) }\end{array}$ \\
\hline 1. & PK - TPK $=0$ & 0 \\
2. & PK $-\mathrm{M}=0$ & 0 \\
3. & $\mathrm{PK}-\mathrm{PK}=0$ & 0 \\
4. & $\mathrm{TPK}-\mathrm{PK}=0$ & 0 \\
5. & $\mathrm{TPK}-\mathrm{M}=0$ & 0 \\
6. & $\mathrm{TPK}-\mathrm{TPK}=0$ & 0 \\
7. & $\mathrm{M}-\mathrm{PK}=45$ & 100 \\
8. & $\mathrm{M}-\mathrm{TPK}=0$ & 0 \\
9. & $\mathrm{M}-\mathrm{M}=0$ & 0 \\
\hline
\end{tabular}

Berdasarkan pada data yang ditunjukkan Tabel 7 dapat diketahui persentase hasil pergeseran konsepsi peserta didik pada konsep faktor suhu terhadap laju reaksi sebesar 100\%. Pada konsep faktor suhu terhadap laju reaksi seluruh peserta didik yang terdiagnosa mengalami pergeseran konsep. Hal ini menunjukkan bahwa pada peserta didik telah melewati tahap operasional formal (berpikir abstrak) sesuai teori Piaget [13]. Selain itu, mampu menangkap dan memahami konsep yang benar terutama pada konsep abstrak [26].

Tabel 8. Hasil Pergeseran Konsepsi Faktor Katalis Terhadap Laju Reaksi

\begin{tabular}{ccc}
\hline No. & $\begin{array}{c}\text { Hasil Pergeseran } \\
\text { Konsepsi }\end{array}$ & $\begin{array}{c}\text { Persentase } \\
\text { Pergeseran } \\
\text { Miskonsepsi (\%) }\end{array}$ \\
\hline 1. & PK - TPK $=0$ & 0 \\
2. & $\mathrm{PK}-\mathrm{M}=0$ & 0 \\
3. & $\mathrm{PK}-\mathrm{PK}=0$ & 0 \\
4. & $\mathrm{TPK}-\mathrm{PK}=0$ & 0 \\
5. & $\mathrm{TPK}-\mathrm{M}=0$ & 0 \\
6. & $\mathrm{TPK}-\mathrm{TPK}=0$ & 0 \\
7. & $\mathrm{M}-\mathrm{PK}=40$ & 88,89 \\
8. & $\mathrm{M}-\mathrm{TPK}=0$ & 0 \\
9. & $\mathrm{M}-\mathrm{M}=5$ & 11,11 \\
\hline
\end{tabular}

Berdasarkan data yang ditunjukkan Tabel 8 diperoleh persentase hasil pergeseran konsepsi peserta didik pada konsep faktor katalis terhadap laju reaksi sebesar $88,89 \%$. Pada konsep faktor katalis terhadap laju reaksi terdapat 40 peserta didik yang terdiagnosa mengalami pergeseran konsep dan 5 peserta didik yang tidak mengalami perubahan konsep atau tetap mengalami miskonsepsi. Hal ini disebabkan karena peserta 
didik mengalami kesulitan atau kurang mampu memahami dan menangkap konsep yang benar terutama pada konsep abstrak [26]. Hal tersebut sesuai dengan teori perkembangan kognitif dari Piaget mengenai tahap operasioanl formal. Ketika peserta didik tidak mampu melewati tahap operasional formal (berpikir abstrak), maka peserta didik akan kesulitan menerima dan memahami materi serta tetap mengalami miskonsepsi [13].

Berdasarkan Tabel 5, Tabel 6, Tabel 7 dan Tabel 8 dapat diketahui bahwa strategi conceptual change text yang digunakan pada software anti chemmisco sangat efektif. Hal ini dikarenakan pada strategi conceptual change text terdiri dari empat tahap [14]. Rincian dari strategi conceptual change text sebagai berikut:

a. Pertama, menunjukkan konsepsi peserta didik. Tahap ini memiliki tujuan utama dalam menyadarkan miskonsepsi yang dialami peserta didik. Bagian pertama ini merupakan langkah dari ketidakpuasan peserta didik terhadap konsepsi yang ada pada dirinya.

b. Kedua, menciptakan konflik konseptual. Dengan kata lain ini adalah bagian dimana konflik dibuat untuk memperkuat ketidakpuasan peserta didik akan konsepsi yang ada pada dirinya. Peserta didik didorong untuk berpikir lebih mengenai topik tersebut sehingga pikiran peserta didik terjebak dalam kebingungan dan ketidakpastian.

c. Ketiga, proses equilibrasi. Pada bagian ini kebenaran ilmiah mengenai konsep yang ditujukan diberikan dengan sangat jelas dan harus dimengerti. Sebagai contoh harus didukung dengan grafik, gambar dan video, yang merupakan alat visual yang mudah menarik perhatian peserta didik dan membuat pengetahuan menjadi permanen.

d. Keempat, rekonstruksi konsep. Ketika peserta didik memahami perbedaan miskonsepsi dan penjelasan ilmiah yang benar, mereka diminta untuk mengerjakan beberapa soal. Bagian ini bertujuan untuk mengukur tingkat kesadaran yang telah dibangkitkan dan melihat apakah peserta didik masih mengalami miskonsepsi.

Berdasarkan empat tahap tersebut maka peserta didik menjadikan software anti chemmico yang dikembangkan sangat efektif dalam menggeser keadaan miskonsepsi pada peserta didik menjadi paham konsep.

\section{PENUTUP \\ SIMPULAN}

Berdasarkan pada pembahasan yang diuraikan diatas maka dapat disimpulkan bahwa pengembangan software anti chemmisco tersebut layak digunakan sebagai pendeteksi dan pereduksi miskonsepsi pada materi laju reaksi yang telah memenuhi krtiteria kelayakan sebagai berikut:

1. Validitas software ditinjau dari hasil validasi isi dan konstruk. Validasi isi memperoleh rata-rata persentase sebesar $94,65 \%$ dan validasi konstruk memperoleh persentase rata-rata sebesar 91,99\%. Dari persentase ini software dikatakan valid.

2. Kepraktisan software ditinjau berdasarkan hasil dari angket respon peserta didik didukung dengan data hasil observasi aktivitas peserta didik. Hasil dari penilaian angket respon peserta didik mendapatkan persentase rata-rata $96 \%$ dan hasil observasi peserta didik sebesar $100 \%$. Berdasarkan perolehan persentase ini software dikatakan praktis.

3. Keefektifan software ditinjau berdasarkan pergeseran konsepsi peserta didik dari miskonsepsi menjadi paham konsep yang mendapatkan rata-rata persentase sebesar $91,64 \%$. Berdasarkan persentase pergesaran ini software dikatakan efektif.

\section{DAFTAR PUSTAKA}

1. Sirhan, G. 2007. Learning Difficulties in Chemistry. Journal of Turkish Science Education., Vol 4, No 2, pp. 2-20.

2. Fahmi., \& Irhasyuarna, Y. 2017. Misconceptions Of Reaction Rates on High School Level in Banjarmasin. Iosr. Journal Of Research \& Method In Education., Vol 7, No 1, pp. 54-61.

3. Ibrahim, M. 2012. Konsep, Miskonsepsi, dan Cara Pembelajarannya. Surabaya: Unesa University Press.

4. Sholehah, S., \& Suyono. 2014. Reduksi Miskonsepsi dengan Model Pembelajaran Conceptual Change pada Konsep Stoikiometri. UNESA Journal Of Chemical Education., Vol 3, No 3, pp. 161-168. 
5. Usu, N., Rahmanpiu \& Mahardi, A. 2019. Analisis Miskonsepsi Siswa pada Materi Kesetimbangan Kimia Menggunakan Tes Diagnostik Two Tier Multiple Choice. Jurnal Pendidikan Kimia FKIP Unoversitas Halu Oleo., Vol 4, No 3, pp. 226-237.

6. Sheftyawan, W.B., Trapsilo \& Albertus. 2018. Identifikasi Miskonsepsi Siswa Menggunakan Four-Tier Diagnostic Test pada Materi Optik Geometri. Jurnal Pembelajaran Fisika., Vol 7, No 2, pp. 147-153.

7. Guzzetti, B. J. 2000. Learning CounterIntuitive Science Concepts: What Have We Learned From Over a Decade of Research. Reading and Writing Quarterly., Vol 16, No 1, pp. 89-98.

8. Jefriadi, Rachmat Sahputra \& Erlina. 2012. Deskripsi Kemampuan Representasi Mikroskopik dan Simbolik Siswa SMA Negeri di Kabupaten Sambas Materi Hidrolisis Garam. Jurnal Pendidikan Kimia FKIP Untan, Vol. 1 , No. 3, pp 1-13.

9. Davis, J. 2001. Introduction to Conceptual Change. http://epltt.coe.uga.edu/Index.php?titl e=//conceptualchange. Diakses 20 Februari 2019.

10.Suprianto, \& Sukarmin. 2016. Pengembangan Software Pengukur Tingkat Konflik Kognitif Kimia. UNESA Journal of Chemical Education. 5 (2). 192-199.

11.Nuha, W. U., \& Sukarmin. 2013. Pengembangan Software Pendeteksi Miskonsepsi Kimia. UNESA Journal of Chemical Education., Vol 2, No 3, pp. 85-89.

12.Sugiarti, F., \& Sukarmin. 2019. Mendeteksi dan Mereduksi Miskonsepsi dengan Menggunakan Software Dered Misequilibri pada Materi Kesetimbangan Kimia. UNESA Journal of Chemical Education., Vol 8, No 1, pp. 94-100.

13.Slavin, R.E. 2011. Psikologi Pendidikan Teori dan Praktik. Jakarta: Indeks.

14.Ozkan, G. \& Selcuk, G.S. 2015. Effect of Technology Enhanced Conceptual Change Text on Students's Understanding of Buoyant
Force. Universal Journal of Educational Research., Vol 3, No 12, pp. 981-988.

15.Sugiyono. 2017. Metode Penelitian Kuantitatif, Kualitatif , dan $R \& D$. Bandung: Alfabeta.

16.Riduwan. 2015. Skala Pengukuran VariabelVariabel Penelitian. Bandung: Alfabeta.

17.Pajaindo, dkk. 2013. Menggali Pemahaman Peserta Didik SMA pada Konsep Laju Reaksi Menggunakan Instrumen Diagnostik TwoTier. Jurnal Pendidikan Kimia., Vol 1, No 1, pp. 1-6.

18.Alwi, S. 2017. Problematika Guru dalam Pengembangan Media Pembelajaran. Itqan., Vol 8, No 2, pp. 145-167.

19.Nurhidayatullah, N. \& Prodjosantoso, A.K. 2018. Miskonsepsi Materi Larutan Penyangga. Jurnal Inovasi Pendidikan IPA., Vol 4, No 1, pp. 41-51.

20.Prastya, A. 2016. Strategi Pemilihan Media Pembelajaran Bagi Seorang Guru. Prosiding Temu Ilmiah Nasional Guru., Vol 1, No 8, pp. 294-302.

21.Gurel, D.K., Eryilmaz, A., \& McDermott, L.C. 2015. A Review and Comparison of Diagnostic Instruments to Identify Student's Misconceptions in Science. Eurasia Journal of Mathematics, Science \& Technology Education., Vol 11, No 15, pp. 989-1008.

22.Rustan, S. 2008. Layout Dasar \& Penerapannya. Jakarta: PT Gramedia Pustaka Utama.

23.Supriyono, R. 2010. Desain Komunikasi Visual: Teori dan Aplikasi. Yogyakarta: Andi.

24.Sriraman \& English. 2010. Theories of Mathematics Education. New York: SpringerVerlag Berlin Heidelberg.

25.Saptono, Y. J. 2016. Motivasi dan Keberhasilan Belajar Siswa. Jurnal Regula Fidei., Vol 1, No 1, pp. 189-212.

26.Asy'ari, M. 2018. Identifikasi Miskonsepsi Mahasiswa Pendidikan Fisika pada Materi Rangkaian Listrik. Jurnal Ilmiah Pendidikan Fisika., Vol 4, No 2, pp. 98-105. 